\title{
THE EFFECTIVENESS OF BUZZ GROUPS METHOD TO TEACH READING COMPREHENSION VIEWED FROM STUDENTS' LEARNING MOTIVATION (AN EXPERIMENTAL STUDY AT THE MECHANICAL ENGINEERING DEPARTMENT STUDENTS OF BALIKPAPAN STATE POLYTECHNIC)
}

\author{
Elisabeth Milaningrum $^{1 *}$, Subur Mulyanto ${ }^{2}$ \\ ${ }^{1,2}$ Dept of Mechanical Engineering, State Polytechnic of Balikpapan \\ *e-mail: elisabethmilaningrum89@gmail.com
}

\begin{abstract}
This research is aimed at finding out whether: (1) Buzz Groups Method is more effective than Direct Instruction Method to teach reading comprehension at mechanical engineering department students of Balikpapan State Polytechnic; (2) the students who have high motivation have better reading comprehension than those who have low motivation at mechanical engineering department of Balikpapan State Polytechnic; and (3) there is an interaction between teaching methods and students' learning motivation for teaching reading comprehension at mechanical engineering department of Balikpapan State Polytechnic. The method which was applied in this research was experimental study. It was conducted at Balikpapan State Polytechnic. The population of the research is the mechanical engineering department student in Balikpapan State Polytechnic. The samples were two classes. Each class was divided into two groups (the students who have high and low motivation). The data analysis shows the following findings: (1) Buzz Groups Method is more effective than Direct Instruction Method to teach reading comprehension to the mechanical engineering department students; (2) The students having high motivation have better reading comprehension than those having low-one; and (3) There is an interaction between the teaching methods and students' learning motivation for teaching reading comprehension. It means that the effectiveness of the teaching methods depends on the degree of the students' learning motivation to the mechanical engineering department students.
\end{abstract}

Keyword: Teaching methods, Reading Comprehension, Students’ Learning Motivation

\section{Introduction}

English is regarded as a foreign language in Indonesia. It is a compulsory subject taught from elementary school up to university. There are four major skills which are important to be learnt in learning English, they are: listening, speaking, reading, and writing. Reading and listening are said to be passive or receptive skills, while writing and speaking are said to be active and productive skills. The aim of English instruction in Balikpapan State Polytechnic is emphasized on developing the students' communicative competence. Teacher should teach students how to use the language to communicate, both in oral and written forms. Reading is one of the ways to communicate in written forms.
Reading implies both a writer and a reader. A writer puts his ideas onto the page and the reader tries to understand the author's meaning and thinks about what he has read. Because it is used to communicate, when reading one needs to figure out what is being read. In other words, one should comprehend or understand the ideas. According to Aebersold and Field (1997: 15), reading is what happens when people look at a text and assign meaning to the written symbols in that text. Moreover, William (1999: 12) defines reading as a process whereby one looks at and understand what has been written. From both definitions, it can be concluded that reading is a process of assign meaning to get information by comprehending the written text. Comprehending is the ability of the reader to understand and gain meaning from what 
has been read in written texts. Reading and understanding are related to each other. Reading itself contains the activity to understand the text and information in the text. In order to understand or to get points from text, we need comprehension for it. Therefore, reading cannot be separated from comprehension.

According to Johnson and Pearson in Darmiyati (2007:16), there are two causes of low learning English reading achievement. They are coming from external and internal factors. Teaching method as external factors used by the teachers also influence the success of the learning of English reading. Teaching method is also one factor that creates a tense classroom. Some lectures in Balikpapan State Polytechnic still use direct instruction method in a classroom. According to Borrich (1996:224), direct instruction method is a teacher-centered method in which teachers are the major information providers. This method is focused on providing verbal explanation by the teacher to large group of the students in order to make them understand the material optimally. In teaching reading, direct instruction method is quite passive and tense since the teacher just asks the students to translate the reading text and do the workheet in the textbook.

While direct instruction method is a teacher-centered method in which teachers are the major information providers, Buzz Groups method offers a method which makes the students as a center of the teaching learning process rather than the teacher-centered. Buzz Groups method is a small discussion group formed for a specific task such as generating ideas, solving problems or reaching a common viewpoint on a topic within a specific period of time. Large groups may be divided into buzz groups in order to cover different aspects of a topic or maximize participation. Unlike direct instruction method that focused on reading translation and task, Buzz Groups method allows students to be actively involved in reading discussion, fostering positive interdependence among groups, and developing communicative skill. The students can elaborate their knowledge to solve the reading problems within the groups. Buzz Groups method is particularly useful in larger classes and also encourages shyer students to participate. In fact, some students have trouble participating in large group discussions or meetings, so by dividing the whole class into small groups, more students have the opportunity to express their thoughts because students have a chance to practice their comments and to increase their repertoire of ideas in their buzz groups.

Besides the teaching method, the students' reading skill is also influenced by motivation. Motivation is one of the internal factors that is very important in teaching and learning process. According to Weiner in Elliot, et al (2000: 332) states that motivation is an internal state that arouses us to action, pushes us in particular direction, and keep us engaged in certain activities. It assumes that motivation has a great role in determining the success of learning process to reach the goal of learning and the students' activeness. It means that the students with low motivation or unmotivated students probably will face difficulties in learning process while students with high motivation or highly motivated students can reach the learning's objectives easily.

In this study, the writer focuses on the two teaching methods above, direct instruction method and buzz groups method. In order to investigate the effects of teaching methods, direct instruction method and buzz groups method, viewed from the students' learning motivation to teach reading comprehension, the writer adopts an experimental research. Buzz Groups method used as experimental variable and direct instruction method as control variable. Meanwhile, reading comprehension is placed as a dependent 
variable. This investigation is to know the difference of both methods and which one is effective or better applied in teaching reading in Balikpapan State Polytechnic. Then, the writer also considers students' learning motivation as simple effect or moderator variable (high or low) to know whether direct instruction method and buzz groups method is suitable for students who have high or low motivation.

This research focuses on the problems formulated as follows:

1. Is buzz groups method more effective than direct instruction method to teach reading comprehension to the mechanical engineering department students of Balikpapan State Polytechnic?

2. Do students who have high motivation have better reading comprehension than those who have low motivation of the mechanical engineering department students of Balikpapan State Polytechnic?

3. Is there any interaction effect between teaching methods and students' motivation to teach reading comprehension to mechanical engineering department students of Balikpapan State Polytechnic?

This research aimed at finding out the influences of the teaching method and the students' motivation on the students' reading comprehension. In detail, this research has the objectives to find out :

1. Wheter Buzz groups method is more efective than direct instruction method to teach reading comprehension;

2. Wheter students who have high motivation have better reading comprehension than those who have low motivation;

3. Wheter there is an interaction effect between teaching methods and students' motivation on the students' reading comprehension.

\section{Research Methodology}

This study was done from October up to November 2015 at the mechanical engineering department students of Balikpapan State Polytechnic.

The method used in conducting this research was an experimental method. . Johnson and Christensen (2000: 23) state that the purpose of experimental research is to determine cause-and-effect relationships.

In parallel with this research, related to the effectiveness of teaching methods used as the independent variables and the motivation as the moderator variable in teaching reading comprehension for the the mechanical engineering department students of Balikpapan State Polytechnic, the writer determined the experimental research methodology. The research design used in this research was a simple factorial design. Cohen, Manion, and Morrison (2007: 281) state that factorial designs also have to take account of the interaction of the independent variables. This research used three kinds of variables. They were: (1) independent variables; (2) dependent variable; and (3) moderator variable. The independent variable in this research was the teaching methods. The teaching methods were the factors of this study manipulated, measured, and selected to know the effect and the relationship to the reality investigated. The teaching methods used in this research were Buzz Groups Method and the Direct Instruction Methods. These two different methods were clung to two groups of students. Buzz Groups Method functioned as an experimental group whereas the other one functioned as a control one. In this research, the target population of this study was all of students at the mechanical engineering department of Balikpapan State Polytechnic.

Sample is a number of individuals for a study in such a way that the individuals represent the larger group from which they were selected (Gay, 1992: 125). The writer decided to choose first semester student at mechanical engineering department that consist of two classes they are class A and class B which 
consists 68 students (34 students from class A and 34 students fromclass B) or two classes from all of population as the sample of this study. In dividing each of the class into the group of high and low motivation, the writer took 17 students who had high motivation and 17 students who had low motivation from first semester students at mechanical engineering student (Experimental class). Furthermore, the writer took 17 students who had high motivation and 17 students who had low motivation from grade VIII-F (Control class). In determining the sample into the experimental and control groups, the researcher applied cluster random sampling and did not use random assignment. So, this research is categorized as a quasi experimental research.

Sampling is the process of selecting a number of individuals for a study in such a way that the individuals represent the larger group from which they were selected (Gay, 1992: 140). The sampling technique used in this study is cluster random sampling technique. Cluster sampling is a sampling in which groups, not individuals, are randomly selected (Gay, 1992: 132). In this case, all members of selected groups have similar characteristics. Based on this idea cluster sampling is a sampling technique that chooses the sample of study by taking certain classes that have similar characteristics. So, among the seven classes, the writer decided to take only two classes (class A and class B on the first semester) randomly as the sample of the study, which consisted of 68 students. In this case, 34 students were taken from class A and 34 students from class B. This number of sample was considered representative enough used as a subject of research.

In conducting this research, the writer also used questionnaire to measure students' motivation. The score from 4 to 1 was for positive statements, whereas negative statement scores were 1 to 4 .
The method used in analyzing the data of this study was descriptive and inferential analysis. Descriptive analysis was used to know the mean, median, mode, and standard deviation of students' scores in reading skill, whereas inferential analysis to know normality and homogeneity tests.

\section{Result and Discussion Hypotheses Testing}

Table 3. 1. Summary of Mean Scores

\begin{tabular}{|c|c|c|c|}
\hline Method & $\begin{array}{c}\text { BGM } \\
A_{i}\end{array}$ & $\begin{array}{c}\text { DIM } \\
A_{2}\end{array}$ & Total Rows \\
\hline \multirow[t]{2}{*}{ High $B_{1}$} & $\begin{array}{l}87 \\
83 \\
87 \\
87 \\
83 \\
80 \\
73 \\
83 \\
77 \\
77 \\
80 \\
80 \\
77 \\
83 \\
73 \\
70 \\
73\end{array}$ & $\begin{array}{l}67 \\
60 \\
57 \\
67 \\
63 \\
60 \\
50 \\
63 \\
60 \\
60 \\
50 \\
63 \\
63 \\
63 \\
53 \\
63 \\
67\end{array}$ & $\begin{array}{l} \\
\\
r_{1} \\
\text { Sum }=2382 \\
\text { Mean }=70.06\end{array}$ \\
\hline & $\begin{array}{c}\text { Sum= } \\
1353 \\
\text { Mean=7 } \\
9.588\end{array}$ & $\begin{array}{c}\text { Sum= } \\
1353 \\
\text { Mean=79. } \\
58\end{array}$ & \\
\hline \multirow[t]{3}{*}{ Low $B_{2}$} & $\begin{array}{l}63 \\
73 \\
67 \\
63 \\
67 \\
57 \\
70 \\
63 \\
63 \\
60 \\
57 \\
63 \\
67 \\
63 \\
67 \\
67 \\
70 \\
\end{array}$ & $\begin{array}{l}73 \\
70 \\
73 \\
70 \\
73 \\
67 \\
70 \\
67 \\
70 \\
60 \\
70 \\
73 \\
73 \\
67 \\
70 \\
77 \\
73 \\
\end{array}$ & $\begin{array}{l}r_{2} \\
\text { Sum=2296 } \\
\text { Mean=67.53 }\end{array}$ \\
\hline & $\begin{array}{l}\text { Sum }= \\
1100 \\
\text { Mean= } \\
64.71\end{array}$ & $\begin{array}{l}\text { Sum= } \\
1196 \\
\text { Mean= } \\
70.35\end{array}$ & \\
\hline & $\begin{array}{l}\text { Sum= } \\
2453\end{array}$ & $\begin{array}{l}\text { Sum }=222 \\
5\end{array}$ & $\begin{array}{l}\text { Sum }=4678 \\
\text { Mean }=68.79\end{array}$ \\
\hline
\end{tabular}




\begin{tabular}{|l|l|l|l|}
\hline & Mean= & Mean=65. & \\
72.15 & 44 \\
\hline
\end{tabular}

Table 3. 2 The Summary of Multifactor Variance $2 \times 2$

\begin{tabular}{|l|c|c|c|c|c|}
\hline \multicolumn{1}{|c|}{$\begin{array}{c}\text { Source of } \\
\text { Varians }\end{array}$} & SS & $\begin{array}{c}\text { D } \\
\text { f }\end{array}$ & MS & $F_{\circ}$ & $F_{\text {to.05 }}$ \\
\hline $\begin{array}{l}\text { Between } \\
\text { Columns }\end{array}$ & 764.47 & 1 & 764.47 & 33.841 & 3.99 \\
$\begin{array}{l}\text { Between } \\
\text { rows }\end{array}$ & 2594.1 & 1 & 2594.1 & 114.83 & 3.99 \\
$\begin{array}{l}\text { Columns by } \\
\text { rows }\end{array}$ & 2 & 1 & 108.76 & 4.815 & 3.99 \\
\hline $\begin{array}{l}\text { Between } \\
\text { Group }\end{array}$ & 3286. & 3 & 1155.7 & 4 & \\
Within & 3842. & 4 & 22.59 & & \\
Group & 59 & & & & \\
\hline Total & 7128. & 6 & 73.33 & & \\
\hline
\end{tabular}

Based on the table above, it can be concluded that:

1. Because $F_{o}$ between columns (33.841) is bigger than $F_{t}$ at the level of significance $\alpha=0.05$ (3.99), the difference between columns is significant. It can be concluded that the methods of teaching reading comprehension are different significantly from one another.

2. Because $F$ row between rows (4.815) is bigger than $\mathrm{Ft}$ at the level of significance $\alpha=0.05$ (3.99), the difference between rows is significant. It can be concluded that the students who have high and those who have low motivation are significantly different in their reading ability.

3. Because $F$ interaction between group (114.834) is bigger than Ft at the level of significance $\alpha=0.05$ (3.99). There is an interaction between the teaching methods and students' motivation. Thus, it can be stated that the effectiveness of teaching methods depends on the degree of students' motivation.
Table 3.3. The Summary of Tukey Test

\begin{tabular}{|c|c|c|c|c|}
\hline $\begin{array}{c}\text { Between } \\
\text { Group }\end{array}$ & $\mathrm{q}_{\mathrm{o}}$ & $\mathrm{q}_{\mathrm{t}}$ & Status & Meaning \\
\hline $\mathrm{A}_{1}-\mathrm{A}_{2}$ & 8.23 & 2.89 & Significant & $\mathrm{A}_{1} \neq \mathrm{A}_{2}$ \\
\hline $\mathrm{B}_{1}-\mathrm{B}_{2}$ & 3.10 & 2.89 & Significant & $\mathrm{B}_{1} \neq \mathrm{B}_{2}$ \\
\hline $\begin{array}{c}\mathrm{A}_{1} \mathrm{~B}_{1}- \\
\mathrm{A}_{2} \mathrm{~B}_{1}\end{array}$ & 12.91 & 2.98 & Significant & $\begin{array}{c}\mathrm{A}_{1} \mathrm{~B}_{1} \neq \\
\mathrm{A}_{1} \mathrm{~B}_{1}\end{array}$ \\
\hline $\begin{array}{c}\mathrm{A}_{1} \mathrm{~B}_{2}- \\
\mathrm{A}_{2} \mathrm{~B}_{2}\end{array}$ & 4.90 & 2.98 & Significant & $\begin{array}{c}\mathrm{A}_{1} \mathrm{~B}_{2} \neq \\
\mathrm{A}_{2} \mathrm{~B}_{2}\end{array}$ \\
\hline
\end{tabular}

1) Because $q_{o}$ between columns (8.23) is higher than $\mathrm{q}_{\mathrm{t}}$ at the level of significance $\alpha=0.05$ (2.89), applying Buzz Groups method differs significantly from Direct Instruction method to teach reading comprehension. Because the mean of $A_{1}$ (73.12) is higher than $A_{2}$ (65.82), it can be concluded that Buzz Groups method is more effective than Direct Instruction method to teach reading comprehension.

2) Because $q_{o}$ between rows (3.10) is higher than $\mathrm{q}_{\mathrm{t}}$ at the level of significance $\alpha=0.05$ (2.89), it can be concluded that the students who have high motivation and those who have low motivation are significantly different in their reading comprehension. Because the mean of B1 (69.47) is higher than B2 (67.91), it can be concluded that the students who have high motivation have better reading comprehension than those who have low motivation.

3) Because qo between cells A1B1 and A2B1 (12.91) is higher than qt at the level of significance $\alpha=0.05$ (2.98), applying Buzz Groups method differs significantly from Direct Instruction method for teaching reading comprehension to the students who have high motivation. Because the mean of $A_{1} B_{1}$ (79.26) is higher than $\mathrm{A}_{2} \mathrm{~B}_{1}$ (60.68) ,it can be concluded that Buzz Groups method is more effective than Direct Instruction method for teaching reading comprehension to the students having high motivation. 
4) Because $q_{o}$ between cells $A_{1} B_{2}$ and $A_{2} B_{2}$ (4.90) is higher than $\mathrm{q}_{t}$ at the level of significance $\alpha=0.05$ (2.98), applying Direct Instruction method differs significantly from Buzz Groups method for teaching reading comprehension to the students who have low motivation. Because the mean of $\mathrm{A}_{1} \mathrm{~B}_{2}$ (64.85) is lower than $\mathrm{A}_{2} \mathrm{~B}_{2}$ (70.21), it can be concluded that Direct Instruction method is more effective than Buzz Groups method for teaching reading comprehension to the students who have low motivation.

By virtue of the above data analysis, here are some conclusions :

1. There is a significant difference on the effect between teaching reading using Buzz Groups method and teaching reading using Direct Instruction method. Teaching reading using Buzz Groups method to the mechanical engineering department students is more effective than the one of those having Direct Instruction method. Buzz Groups method as one of many methods in cooperative learning. Buzz Groups method allows students to be actively involved in reading discussion, fostering positive interdependence among groups, and developing communicative skill. The students can elaborate their knowledge to solve the reading problems within the groups. Buzz Groups method is particularly useful in larger classes and also encourages shyer students to participate since some students have trouble participating in large group discussions or meetings. Therefore, by dividing the whole class into small groups, more students have the opportunity to express their thoughts because students have a chance to practice their comments and to increase their repertoire of ideas in their buzz groups. Moreover, Buzz groups method is very useful for large groups to get feedback from a large number of students on specific topic in a formalized way and within specific time. When one individual gives response to the problem, she/he stimulates further analysis for another member of the group. This will lead other students to refine their thinking by giving feedback or share their different ideas. Students will create interaction to each other in discussing text. Meanwhile Direct Instruction method makes the students depend on the teacher's explanation in reading class. Teachers are the major information providers. This method only focused on providing verbal explanation by the teacher to large group of the students in order to make them understand the material optimally. The students tend to be passive and no courage to share their ideas to his/her friends. Because of that, they are not active and do not develop their knowledge. It is in line with Sanjaya (2009: 191) that explained about Direct Instruction method which only depend on the teacher's competence such as their preparation, confidence, knowledge, enthusiasm, motivation, and also their classroom management. He also added that Direct Instruction method has a one-way communication style that makes the limited chance to the teacher to control the students' understanding for the material given.

2. There is a significant difference in reading comprehension between students with high motivation and those with low motivation. Reading comprehension of the students having high motivation is better than those having low learning motivation. Sardiman (1992: 75) states that learning motivation has specific roles in promoting learning enthusiasm, joy, and interest. Highly motivated students are usually active, curious, performing hard effort to gain the goal, enthusiastic, and courageous are to take risk for their learning. Curiosity makes them challenged to find more learning resources based on their needs. Courage makes them brave to express ideas and to 
practice which means more chance for them for learning. Low motivated students do not often perform hard effort to learn more. They are not actively involved in the learning activities. They do not have enough courage to take risk to enrich their knowledge. They prefer listening to the teacher to having effort to do anything by them.

3. There is an interaction between teaching method and motivation. The teaching method that used by the teacher in the class give a big influence for the success of the teaching and learning process. Good teaching method in the class challenge students to perform a better learning and increase students' motivation. Students are more activated to learn when they taught using challenging and interesting teaching method. Buzz Groups method is one of the challenging method that automatically force the students to be actively engaged in the classroom since it has a good structure that appears in how it builds students' knowledge around individual responses. When it is applied in the classroom activity, the highly motivated students will be more motivated to learn. It is in line with Harmer (1991: 5-6) that suggests some factors that affecting intrinsic motivation in language learning. One of them is teaching method that is used by the teacher. Good teaching method will give effect on students' intrinsic motivation. Meanwhile, Direct Instruction Method is more suitable for low motivated students.

\section{Conclusion}

Based on the data descriptions analysis, the researcher presents the findings as follows:

1. Buzz Groups Method is more effective than Direct Instruction Method to teach reading comprehension for the mechanical department students at Balikpapan State Polytechnic.
2. The students having high motivation have better reading comprehension than those having low motivation for the the mechanical department students at Balikpapan State Polytechnic.

3. There is an interaction between the teaching methods and students' motivation in teaching reading comprehension.

\section{Acknowledgment}

This research is aimed for students who have difficulty in English TOEFL especially in reading comprehension and also as the additional teaching method for the English lecturer when they teach TOEFL preparation in class. Thank you to P3M in Balikpapan State Polytechnic for your support.

\section{References}

[1] Aebersold, Jo and Field Mary Lee. 1997. From Reader to Reading Teacher. Cambridge: Cambridge University Press.

[2] Barkley. et al. 2001. Collaborative Learning Techniques. San Francisco: Jossey-Bass.

[3] Borrich, Gary D. 1996. Effective Teaching Methods. $3^{\text {rd }}$ Prentice Hall. Inc: New Jersey.

[4] Brown, H. Douglas. 1994. Principles of Language Learning and Teaching. New Jersey: Prentice Hall Regency.

[5] Burns, Anne. 1999. Collaborative Action Research For English Language Teachers. Cambridge: Cambridge University Press.

[6] Cruickshank, Donald R, Bainer. 1999. The Act of Teaching. Boston: Macgraw-Hill College.

[7] Elliot, Stephen. 2000. Educational Psychology: Effective Teaching Effective Learning. USA: McGraw Hill Company.

[8] Grellet, Francoise. 1998. Developing Reading Skill. Cambridge: Cambridge University Press.

[9] Harmer, Jeremy. 1998. How to Teach English. An Introduction to the Practice of Language Teaching. Longman: Wesley Longman. 
[10] Heilman, Arthur W and Blair, Timothy R. 1981. Principles and practices of Teaching Reading. Columbus: Charles E. Merill Publishin

[11] Kennedy, Eddie C. 1981. Methods in teaching Developmental Reading Second Edition. USA: F.E Peacock Publishers, Inc.

[12] Nunan, David. 1992. Research Methods in Language Learning. Cambridge: Cambridge University Press.[13] Nuttal, C. 1996. Teaching Reading Skills in a foreign language. Mexico: Heinemann.
[14] Richards C., Jack. 1997. From Reader to Reading Teacher. Cambridge: Cambridge University Press.

[15] Slavin, R. 1997. Educational Psychology: Theory and Practice (5th $E d$.). Boston: Allyn and Bacon, Inc.

[16] Tuckman, Bruce W. 1978. Conducting Education Research. New York: Harcourt Brace Jovanivich, Inc.

[17] William, Eddie. 1999. Reading in the Language Classroom. London: Phoenix FLT. 